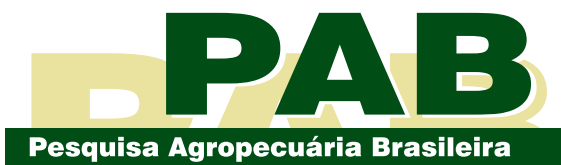

ISSN 1678-3921

Journal homepage: www.embrapa.br/pab

For manuscript submission and journal contents, access: www.scielo.br/pab

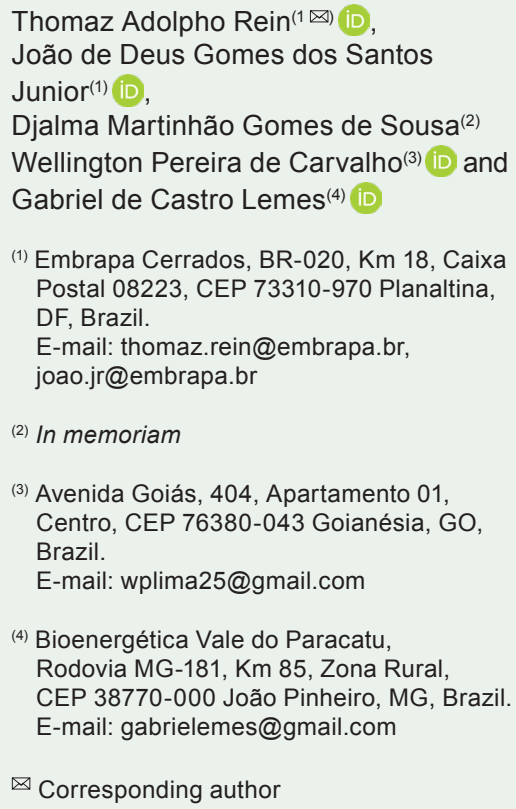

Received

August 28, 2020

Accepted

May 12, 2021

How to cite

REIN, T.A.; SANTOS JUNIOR, J. de D.G. dos; SOUSA, D.M.G. de; CARVALHO, W.P. de ; LEMES, G. de C. Corrective and maintenance phosphorus fertilization on sugarcane yield in Oxisols. Pesquisa Agropecuária Brasileira, v.56, e02160, 2021 DOI: https://doi.org/10.1590/S1678-3921. pab2021.v56.02160.

\section{Corrective and maintenance phosphorus fertilization on sugarcane yield in Oxisols}

\begin{abstract}
The objective of this work was to evaluate sugarcane (Saccharum spp.) yield in response to corrective and maintenance phosphorus fertilization in Oxisols. Two experiments were carried out in randomized complete blocks with four replicates. In the corrective fertilization treatments, $150 \mathrm{~kg} \mathrm{ha}^{-1}$ $\mathrm{P}_{2} \mathrm{O}_{5}$ were broadcast and incorporated before planting. In the maintenance fertilization treatments, $40 \mathrm{~kg} \mathrm{ha}^{-1} \mathrm{P}_{2} \mathrm{O}_{5}$ per year were applied over the trash blanket. All treatments, except the control, were fertilized with $170 \mathrm{~kg} \mathrm{ha}^{-1} \mathrm{P}_{2} \mathrm{O}_{5}$ in the planting furrow. The first experiment was carried out in a sugarcane expansion area and the second, in a replanting area, in Oxisols with a low and high phosphorus availability, respectively. In the first experiment, corrective fertilization increased cane yield in $13.4 \mathrm{Mg} \mathrm{ha}^{-1}$ for plant cane and in 14.6 $\mathrm{Mg} \mathrm{ha}{ }^{-1}$ for the average of four ratoon crops, whereas maintenance fertilization increased yield in 17.7 and $8.1 \mathrm{Mg} \mathrm{ha}^{-1}$ for the average of four ratoon crops for the treatments without and with corrective fertilization, respectively. In the second experiment, there were no significant differences between treatments regarding yield. Corrective and maintenance phosphorus fertilization should be considered for sugarcane in areas where soil phosphorus availability is limiting.
\end{abstract}

Index terms: Saccharum, fertilizer placement, phosphate rock, superphosphate.

\section{Adubação fosfatada corretiva e de manutenção na produtividade de cana-de-açúcar em Latossolos}

Resumo - O objetivo deste trabalho foi avaliar a produtividade da cana-deaçúcar (Saccharum spp.) em resposta à adubação fosfatada corretiva e de manutenção em Latossolos. Dois experimentos foram conduzidos em blocos ao acaso, com quatro repetições. Nos tratamentos com adubação corretiva, foram aplicados $150 \mathrm{~kg} \mathrm{ha}^{-1}$ de $\mathrm{P}_{2} \mathrm{O}_{5}$ a lanço, com incorporação antes do plantio. Nos tratamentos de adubação de manutenção, foram aplicados $40 \mathrm{~kg} \mathrm{ha}^{-1}$ de $\mathrm{P}_{2} \mathrm{O}_{5}$ por ano sobre o palhiço. Todos os tratamentos, exceto o testemunha, foram adubados com $170 \mathrm{~kg} \mathrm{ha}^{-1}$ de $\mathrm{P}_{2} \mathrm{O}_{5}$ no sulco de plantio. $\mathrm{O}$ primeiro experimento foi realizado em área de expansão de cana-deaçúcar e o segundo, em área de reforma, em Latossolos com baixa e alta disponibilidade de fósforo, respectivamente. No primeiro experimento, a adubação corretiva propiciou aumentos na produtividade de colmos de 13,4 $\mathrm{Mg} \mathrm{ha}^{-1}$ para cana-planta e $14,6 \mathrm{Mg} \mathrm{ha}^{-1}$ na média de quatro socas, enquanto a adubação de manutenção propiciou aumentos de produtividade de 17,7 e $8,1 \mathrm{Mg} \mathrm{ha}^{-1}$ na média das socas para os tratamentos sem e com adubação corretiva, respectivamente. No segundo experimento, não houve diferenças significativas entre os tratamentos em relação à produtividade. As adubações fosfatadas corretiva e de manutenção devem ser consideradas para cana-deaçúcar em áreas cuja disponibilidade de fósforo do solo é limitante.

Termos para indexação: Saccharum, localização do fertilizante, fosfato natural, superfosfato. 


\section{Introduction}

A great expansion has been observed in the sugar and ethanol sector in Brazil during the past two decades. In the Midwestern region, made up by the states of Goiás, Mato Grosso, and Mato do Grosso do Sul, and in the mesoregions of the Cerrado biome in the state of Minas Gerais, the area cultivated with sugarcane grew approximately 400 and $350 \%$ from 2000 to 2018, respectively, reaching 1.91 and 0.86 million hectares. Overall, in the country, the growth in sugarcane area was $110 \%$ (IBGE, 2020).

The expansion of sugarcane in the Cerrado biome occurred mainly in areas of pastures and grain crops, and, to a lesser extent, in areas of native vegetation (Ribeiro et al., 2016). Unlike crop areas, most of the pastures in the region are not fertilized and retain the inherited low soil fertility in the case of areas originally under cerrado vegetation (Franco et al., 2015). The soils of these areas are acid and with generalized nutrient deficiencies, among which that of phosphorus stands out as the main limiting factor for agricultural production (Sousa et al., 2004).

Phosphorus fertilization of sugarcane is traditionally based on high rates, up to $180 \mathrm{~kg} \mathrm{ha}^{-1} \mathrm{P}_{2} \mathrm{O}_{5}$, applied to the bottom of the planting furrow (Spironello et al., 1996). Broadcast-incorporated corrective fertilization to build-up the status of soil phosphorus, in addition to phosphorus fertilization in the planting furrow, is recommended for crops, in general, in the Cerrado region (Sousa et al., 2004), as well as for sugarcane (Luz \& Vitti, 2008; Rein et al., 2015; Korndörfer et al., 2017). However, it is still not a widespread practice for this crop. Sugarcane yield increases and economic returns due to corrective phosphorus fertilization have been reported in the northern part of the state of Goiás, in soils with a low phosphorus availability (Gama, 2007; Sousa et al., 2015).

Maintenance phosphorus fertilization of ratoon crops is also not a widespread practice in the production of sugarcane in Brazil, although it has been increasing, but with controversies regarding yield responses and fertilizer use efficiency (Penatti, 2013). A compilation of experimental results showed frequent yield increases with maintenance phosphorus fertilization in soils with a low phosphorus availability (Rein et al., 2015). However, in soils representative of the southern part of the state of Goiás, an important sugar and ethanol production region in Brazil, no known experimental data is available on phosphorus fertilization management for the sugarcane crop.

The objective of this work was to evaluate sugarcane yield in response to corrective and maintenance phosphorus fertilization in Oxisols.

\section{Materials and Methods}

Two experiments were carried out in sugarcane (Saccharum spp.) production areas of the GoiasaGoiatuba Álcool Ltda sugarcane mill, located in the municipality of Goiatuba, in the state of Goiás, Brazil. The climate of the region is classified as Aw, tropical with a dry winter season, according to Köppen's classification. The average annual precipitation is 1,350 $\mathrm{mm}$ (91\% between October and April), and the average minimum and maximum temperatures are 19.9 and $29.3^{\circ} \mathrm{C}$, respectively (Climatempo, 2020). Experiment 1 was established in a sugarcane expansion area $\left(18^{\circ} 06^{\prime} \mathrm{S}, 49^{\circ} 37^{\prime} \mathrm{W}\right.$, at an altitude of $750 \mathrm{~m}$ ) with a Latossolo Vermelho Ácrico according to the Brazilian classification system (Santos et al., 2018a), i.e., a sandy clay loam Anionic Acrustox (Soil Survey Staff, 2014), derived from basic igneous rock and sandstone, previously under pasture of Urochloa brizantha (A.Rich.) R.D.Webster grass. Experiment 2 was established in a sugarcane replanting area $\left(17^{\circ} 56^{\prime} \mathrm{S}, 49^{\circ} 45^{\prime} \mathrm{W}\right.$, at an altitude of $680 \mathrm{~m}$ ) previously cropped with soybean [Glycine $\max$ (L.) Merr.], with a Latossolo Vermelho Acriférrico (Santos et al., 2018a), i.e., a clayey Anionic Acrustox (Soil Survey Staff, 2014), derived from basic igneous rock. Table 1 shows the chemical characterization and textural analysis of the two soils sampled in December 2009, respectively, nine and seven months after experiments 1 and 2 were planted. The soils were sampled in the sugarcane interrow of the control treatment plots (without phosphorus fertilization), with 16 subsamples of each plot being taken at 0-20 and 20-40 cm depths. Analyses were performed following the methods described by Claessen (1997), with the exception of $\mathrm{pH}$ in $0.01 \mathrm{~mol} \mathrm{~L}^{-1} \mathrm{CaCl}_{2}$, titratable acidity at $\mathrm{pH} 7(\mathrm{H}+\mathrm{Al})$, and available phosphorus by the resin method (Raij et al., 2001).

Experiment 1 was planted in mid-March 2009 and experiment 2 at the end of May of the same year in plots of $135 \mathrm{~m}^{2}$ (nine $10 \mathrm{~m}$ rows with $1.5 \mathrm{~m}$ row spacing) and $90 \mathrm{~m}^{2}$ (six $10 \mathrm{~m}$ rows with $1.5 \mathrm{~m}$ row spacing), 
respectively. A total of 3.7 and $3.5 \mathrm{Mg} \mathrm{ha}^{-1}$ dolomitic limestone (approximately 80\% effective calcium carbonate equivalent) was applied in 2008 in the areas of experiments 1 and 2, respectively, and incorporated with a heavy disk harrow at a depth of approximately 20 $\mathrm{cm}$. Crotalaria juncea L. was grown in the expansion area (experiment 1), without fertilization, broken up, and partially incorporated with a disk harrow in February 2009. The soybean crop grown in the replant area (experiment 2) was harvested in April 2009.

Both experiments were carried out in a randomized complete block design with four replicates. The treatments consisted of phosphorus sources (only in experiment 1), rates, and methods of application (Table 2). Since experiment 2 was planted in late May ("winter planting"), already in the dry season, the area was previously irrigated with a sprinkler system before the broadcast application of fertilizers and mechanized operations for incorporating the fertilizers and opening the planting furrows.

The fertilizers used for the corrective fertilization treatments were: granular triple superphosphate $(47 \%$ total $\mathrm{P}_{2} \mathrm{O}_{5}$ and $46 \%$ soluble in neutral ammonium citrate + water), unground commercial Arad phosphate rock from Israel $\left(33 \%\right.$ total $\mathrm{P}_{2} \mathrm{O}_{5}$ and $10.6 \%$ soluble in $2 \%$ citric acid, $1: 100 \mathrm{w} / \mathrm{v})$, and a finely ground $(96 \%<$ $0.074 \mathrm{~mm}$ ) phosphate rock from Arraias, in the state of Tocantins, Brazil $\left(20 \%\right.$ total $\mathrm{P}_{2} \mathrm{O}_{5}$ and $6.5 \%$ soluble in $2 \%$ citric acid, $1: 100 \mathrm{w} / \mathrm{v}$ ). The fertilizers were manually broadcast at 150 or $125 \mathrm{~kg} \mathrm{ha}^{-1} \mathrm{P}_{2} \mathrm{O}_{5}$ in treatments $\mathrm{D}$, $\mathrm{E}, \mathrm{F}$, and $\mathrm{G}$ in experiment 1 and in treatment $\mathrm{E}$ in experiment 2 (Table 2). The plots were split into four

Table 1. Chemical and physical characterization of the soil sampled in the interrow of the control treatment plots of the two experiments (averages of four plots) ${ }^{(1)}$.

\begin{tabular}{|c|c|c|c|c|c|c|c|c|c|c|c|c|}
\hline \multirow{2}{*}{$\begin{array}{l}\text { Depth } \\
\text { (cm) }\end{array}$} & \multirow{2}{*}{$\begin{array}{c}\mathrm{pH} \\
\mathrm{CaCl}_{2}\end{array}$} & \multirow{2}{*}{$\mathrm{Ca}$} & \multirow{2}{*}{$\mathrm{Mg}$} & $\mathrm{K}$ & \multirow[t]{2}{*}{$\mathrm{Al}$} & \multirow{2}{*}{$\mathrm{H}+\mathrm{Al}$} & \multicolumn{2}{|c|}{$\mathrm{P}\left(\mathrm{mg} \mathrm{dm}^{-3}\right)$} & \multirow{2}{*}{ OM } & \multirow{2}{*}{ Clay } & \multirow[t]{2}{*}{ Silt } & \multirow{2}{*}{ Sand } \\
\hline & & & & $\mathrm{ol}_{\mathrm{c}} \mathrm{d}$ & & & Mehlich-1 & Resin & & & & \\
\hline \multicolumn{13}{|c|}{ Experiment $1-$ sandy clay loam Anionic Acrustox } \\
\hline $0-20$ & 5.1 & 2.41 & 0.91 & 0.08 & 0.01 & 2.88 & 3.1 & 9.8 & 17.6 & 323 & 37 & 640 \\
\hline $20-40$ & 4.7 & 0.44 & 0.18 & 0.04 & 0.12 & 3.37 & 0.6 & 2.6 & 14.0 & 325 & 40 & 635 \\
\hline \multicolumn{13}{|c|}{ Experiment 2 - clayey Anionic Acrustox } \\
\hline $0-20$ & 5.3 & 4.32 & 1.94 & 0.12 & 0.01 & 3.52 & 6.3 & 30.6 & 37.2 & 613 & 229 & 158 \\
\hline $20-40$ & 5.2 & 2.72 & 1.62 & 0.05 & 0.03 & 3.57 & 1.4 & 7.9 & 35.7 & 630 & 220 & 150 \\
\hline
\end{tabular}

${ }^{(1)} \mathrm{pH}$ measured in $0.01 \mathrm{~mol} \mathrm{~L}^{-1} \mathrm{CaCl}_{2} ; \mathrm{Ca}, \mathrm{Mg}$, and $\mathrm{Al}$ extracted with $1.0 \mathrm{~mol} \mathrm{~L}-1 \mathrm{KCl} ; \mathrm{K}$ extracted with Mehlich-1 solution; $\mathrm{H}+\mathrm{Al}$ (titratable acidity) extracted with $0.5 \mathrm{~mol} \mathrm{~L}^{-1} \mathrm{Ca}$ acetate at $\mathrm{pH}$ 7.0; P extracted with Mehlich-1 and resin methods; organic matter (OM) obtained by the Walkley-Black method; and textural analysis (clay, silt, and sand) carried out by the pipette method after dispersion with $\mathrm{NaOH}$.

Table 2. Treatments with sources, rates, and methods of application of phosphorus in experiment 1 with sugarcane (Saccharum spp.) expansion and a low phosphorus soil and in experiment 2 with sugarcane replant and a high phosphorus soil.

\begin{tabular}{|c|c|c|c|c|c|c|c|c|c|}
\hline \multirow{3}{*}{ Treatment } & \multicolumn{4}{|c|}{ Experiment 1} & \multirow{3}{*}{ Treatment } & \multicolumn{4}{|c|}{ Experiment 2} \\
\hline & \multicolumn{2}{|c|}{ Corrective $\mathrm{P}$} & \multirow{2}{*}{$\begin{array}{l}\text { Planting } \\
\text { furrow }\end{array}$} & \multirow{2}{*}{$\begin{array}{c}\text { Ratoon } \\
\text { crop }^{(2)}\end{array}$} & & \multicolumn{2}{|c|}{ Corrective fertilization } & \multirow{2}{*}{$\begin{array}{l}\text { Planting } \\
\text { furrow }\end{array}$} & \multirow{2}{*}{$\begin{array}{c}\text { Ratoon } \\
\text { crop }^{(2)}\end{array}$} \\
\hline & Source $^{(1)}$ & Rate & & & & Source & Rate & & \\
\hline \multicolumn{7}{|c|}{-------- $\mathrm{P}_{2} \mathrm{O}_{5}\left(\mathrm{~kg} \mathrm{ha}^{-1}\right)-$} & \multicolumn{3}{|c|}{ - - } \\
\hline A & - & 0 & 0 & 0 & $\mathrm{~A}$ & - & 0 & 0 & 0 \\
\hline B & - & 0 & 170 & 0 & B & - & 0 & 170 & 0 \\
\hline $\mathrm{C}$ & - & 0 & 170 & 40 & $\mathrm{C}$ & - & 0 & $100+70^{(3)}$ & 0 \\
\hline $\mathrm{D}$ & TSP & 150 & 170 & 0 & $\mathrm{D}$ & - & 0 & 170 & 40 \\
\hline $\mathrm{E}$ & TSP & 150 & 170 & 40 & E & TSP & 150 & 170 & 0 \\
\hline $\mathrm{F}$ & Arad PR & 150 & 170 & 0 & - & - & - & - & - \\
\hline G & Arraias PR & 125 & 170 & 0 & - & - & - & - & - \\
\hline $\mathrm{H}$ & - & 0 & $100+70^{(3)}$ & 0 & - & - & - & - & - \\
\hline
\end{tabular}

${ }^{(1)}$ TSP, triple superphosphate; and Arad PR and Arraias PR, Arad and Arraias phosphate rocks, respectively. (2)Maintenance annual phosphorus rate as triple superphosphate. ${ }^{(3)} 100 \mathrm{~kg} \mathrm{ha}^{-1} \mathrm{P}_{2} \mathrm{O}_{5}$ in the planting furrow and $70 \mathrm{~kg} \mathrm{ha}^{-1} \mathrm{P}_{2} \mathrm{O}_{5}$ side-dressed. 
quadrants for a more homogeneous broadcast of the fertilizers, which were incorporated with a disk harrow at approximately $15 \mathrm{~cm}$ depth. The rate of $150 \mathrm{~kg} \mathrm{ha}^{-1}$ $\mathrm{P}_{2} \mathrm{O}_{5}$ was chosen based on the recommendations for corrective phosphorus fertilization for sugarcane and other crops in general in the Cerrado region (Sousa et al., 2004; Korndörfer et al., 2017), as well as on the recommendations for sugarcane in the state of São Paulo in medium-textured soils with a low to medium phosphorous availability (Rosseto et al., 2010; Vitti et al., 2015). The applied superphosphate rate was based on the content of $\mathrm{P}_{2} \mathrm{O}_{5}$ soluble in neutral ammonium citrate + water, whereas the rates of phosphate rocks were based on the total contents of $\mathrm{P}_{2} \mathrm{O}_{5}$.

Afterwards, the planting furrows were mechanically opened at approximately $25 \mathrm{~cm}$ depth, with a furrow spacing of $1.5 \mathrm{~m}$. A commercial bulk blend of monoammonium phosphate and single superphosphate $\left(7 \% \mathrm{~N}, 40 \% \mathrm{P}_{2} \mathrm{O}_{5}\right.$ soluble in neutral ammonium citrate + water, and $4.3 \%$ S) was manually applied at the bottom of the planting furrows, at the corresponding rates of 0,100 , and $170 \mathrm{~kg} \mathrm{ha}^{-1} \mathrm{P}_{2} \mathrm{O}_{5}$, based on the content of $\mathrm{P}_{2} \mathrm{O}_{5}$ soluble in neutral ammonium citrate + water, according to the treatments shown in Table 2 . Nitrogen and sulfur at the rates of 30 and $18 \mathrm{~kg} \mathrm{ha}^{-1}$, respectively, were leveled for all treatments with urea and ammonium sulfate. Micronutrients were also applied to all treatments at the rate of $40 \mathrm{~kg} \mathrm{ha}^{-1}$ of the commercial granular product FTE BR-12 (Nutriplant Indústria e Comércio S.A., Barueri, SP, Brazil), supplying $0.72 \mathrm{~kg} \mathrm{ha}^{-1} \mathrm{~B}, 0.32 \mathrm{~kg} \mathrm{ha}^{-1} \mathrm{Cu}, 0.8 \mathrm{~kg} \mathrm{ha}^{-1}$ $\mathrm{Mn}, 0.04 \mathrm{~kg} \mathrm{ha}^{-1} \mathrm{Mo}$, and $3.6 \mathrm{~kg} \mathrm{ha}^{-1} \mathrm{Zn}$ as oxisulfates. The fertilizers were lightly incorporated with a hoe into the bottom of the planting furrows.

Then, to ensure a good stand, three seed canes of two sugarcane varieties - SP 83-2847 and RB 867515 in experiments 1 and 2, respectively - were manually planted, chopped with a machete into billets of approximately $40 \mathrm{~cm}$, and covered by hoe with 5 to $10 \mathrm{~cm}$ of soil. In experiment 1 (expansion area previously under pasture), before being covered with soil, the chopped canes were sprayed with the fipronil insecticide for termite control at $200 \mathrm{~g} \mathrm{ha}^{-1}$ active ingredient. In experiment 2, planted in late May, already in the dry season, two sprinkler irrigations were carried out just after planting and at the beginning of cane sprouting, to ensure full sprouting.
In August 2009, fertilizers were side-dressed in experiment 1 just before the operation to level the soil along the row and interrow space (manual, with hoe), incorporating the fertilizers applied at both sides of the sugarcane rows. Nitrogen at $60 \mathrm{~kg} \mathrm{ha}^{-1} \mathrm{~N}$ (ammonium sulfate) and potassium at $160 \mathrm{~kg} \mathrm{ha}^{-1} \mathrm{~K}_{2} \mathrm{O}$ (potassium chloride) were applied in all treatments. In the $\mathrm{H}$ treatment plots (Table 2), $70 \mathrm{~kg} \mathrm{ha}^{-1} \mathrm{P}_{2} \mathrm{O}_{5}$ were applied as granular triple superphosphate, based on the neutral ammonium citrate + water soluble content. This split management of phosphorus fertilization for plant cane $\left(100 \mathrm{~kg} \mathrm{ha}^{-1}\right.$ in the planting furrow +70 $\mathrm{kg} \mathrm{ha}^{-1}$ side-dressed) is already adopted at the GoiasaGoiatuba Álcool Ltda sugar mill and was evaluated as a treatment in both experiments.

In experiment 2, the fertilizer side-dressing and soil leveling operations were carried out in November 2009. Nitrogen at $60 \mathrm{~kg} \mathrm{ha}^{-1} \mathrm{~N}$ and potassium at 160 $\mathrm{kg} \mathrm{ha}^{-1} \mathrm{~K}_{2} \mathrm{O}$ were applied for all treatments as a bulk blend of potassium chloride and ammonium nitrate. Triple superphosphate at $70 \mathrm{~kg} \mathrm{ha}^{-1} \mathrm{P}_{2} \mathrm{O}_{5}$ was applied for treatment $\mathrm{C}$ (Table 2), complementing the 100 $\mathrm{kg} \mathrm{ha}^{-1} \mathrm{P}_{2} \mathrm{O}_{5}$ rate in the planting furrow.

Manual harvesting of the plant cane and ratoon crops was done in May for both experiments, except for the first ratoon crop, which was harvested in June 2011. Five crops were harvested for experiment 1 and three for experiment 2. With the exception of plant cane in experiment 1, with pre-harvest burning, the experiments were green harvested. Millable stalk yield was evaluated in the five central rows of experiment 1 $\left(52.5 \mathrm{~m}^{2}\right)$ and in the four central rows of experiment 2 $\left(42 \mathrm{~m}^{2}\right)$, after excluding $1.5 \mathrm{~m}$ borders at each end of the row. Trash (green tops and most of the dry leaves) was separated from the stalks and left on the plots. The cane stacks at the plots were weighed with a dynamometer coupled to a grab loader.

Ten millable stalks from each plot were sampled and processed within 48 hours after harvesting for quality analysis at the Laboratory of Technological Analysis of the Goiasa-Goiatuba Álcool Ltda sugar mill, following the methodologies described in Consecana-SP (2006). Cane quality was expressed as total reducing sugars ( $\mathrm{kg} \mathrm{Mg}^{-1}$ millable stalks), computed from juice Brix and POL and fiber content, with juice being extracted with a hydraulic press. The ten stalk samples from all plots were analyzed in the first three harvests from 2010-2012 of both experiments, but samples from only 
a few treatments were analyzed in the fourth harvest of experiment 1 , and no samples were taken for the last harvest of experiment 1 .

For the maintenance fertilization of the ratoon crops (treatments $\mathrm{C}$ and $\mathrm{E}$ in experiment 1 and treatment $\mathrm{D}$ in experiment 2), triple superphosphate, at the rate of $40 \mathrm{~kg} \mathrm{ha}^{-1} \mathrm{P}_{2} \mathrm{O}_{5}$ (soluble in neutral ammonium citrate + water), was applied every year after harvesting at the beginning of the rainy season around October, on top of the trash blanket at both sides of the cane rows. At the same time, nitrogen and potassium were applied to all plots at $120 \mathrm{~kg} \mathrm{ha}^{-1} \mathrm{~N}$ and $144 \mathrm{~kg} \mathrm{ha}^{-1} \mathrm{~K}_{2} \mathrm{O}$ as a bulk blend of ammonium nitrate and potassium chloride.

Weeds were controlled with pre- and post-emergent herbicides, as well as with manual hoe weeding. The biological control of stem borers was carried out in some of the years by releasing the Cotesia flavipes (Cameron) wasp in the experiments.

The cane yield results of the plant cane and ratoon crops were subjected to the analysis of variance and the t-test, at $5 \%$ probability. Analyzes were performed with the SAS, version 9.3.1, software (SAS Institute Inc., Cary, NC, USA).

\section{Results and Discussion}

Significant cane yield increases were observed with phosphorus fertilization in experiment 1 (Table 3), a sugarcane expansion area after pasture in a sandy clay loam Oxisol, with phosphorous availability in the 0-20 cm layer (Table 1) that was classified as medium by the resin method and low by the Mehlich-1 method (Sousa et al., 2004). The plant cane yield with 170 $\mathrm{kg} \mathrm{ha}^{-1} \mathrm{P}_{2} \mathrm{O}_{5}$ in the planting furrow (treatment B) was 13.2 $\mathrm{Mg} \mathrm{ha}^{-1}$ higher than that of the control (treatment A). In addition, compared with treatment $\mathrm{B}$, there was an average yield increase of $13.4 \mathrm{Mg} \mathrm{ha}^{-1}$ for plant cane in treatments $\mathrm{D}, \mathrm{F}$, and $\mathrm{G}$ (Table 3) with the corrective broadcast-incorporated fertilization with triple superphosphate and with the Arad and Arraias phosphate rocks, respectively, with no significant difference between the three sources. Moreover, the residual effect of corrective fertilization was pronounced. The average yield of the four ratoon crops with the three phosphorus sources was $14.6 \mathrm{Mg} \mathrm{ha}^{-1}$ higher than that of treatment $\mathrm{B}$ without corrective fertilization, which is comparable to the yield response of the studied plant cane. As observed for the studied plant cane, similar yields were obtained for the ratoon crops with the three sources.

In experiment 2, a replanting area following a soybean crop in summer, there were no significant responses of the plant cane and ratoon crops to the phosphorus fertilization treatments (Table 4). These results are consistent with the phosphorus availability in the 0-20 $\mathrm{cm}$ layer of this very clayey Oxisol (Table 1), which is of 6.3 and $30.6 \mathrm{mg} \mathrm{dm}^{-3}$ by the

Table 3. Millable cane yields of plant cane and four ratoon crops in experiment 1 with sugarcane (Saccharum spp.) expansion and a low phosphorus soil(1).

\begin{tabular}{|c|c|c|c|c|c|c|c|c|c|c|}
\hline \multirow[t]{2}{*}{ Treatment } & \multicolumn{2}{|c|}{ Corrective $\mathrm{P}$} & \multirow{2}{*}{$\begin{array}{l}\text { Planting } \\
\text { furrow }\end{array}$} & \multirow{2}{*}{$\begin{array}{l}\text { Ratoon } \\
\text { crop }^{(3)}\end{array}$} & \multicolumn{5}{|c|}{ Cane yield } & \multirow{2}{*}{$\begin{array}{c}\text { Average } \\
2011 / 2014\end{array}$} \\
\hline & Source ${ }^{(2)}$ & Rate & & & 2010 & 2011 & 2012 & 2013 & 2014 & \\
\hline & & \multicolumn{3}{|c|}{ 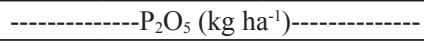 } & - ----- & (-י- & (1 & 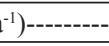 & - & - \\
\hline A & - & 0 & 0 & 0 & 117.4 & 71.4 & 57.6 & 59.7 & 52.8 & 60.4 \\
\hline $\mathrm{B}$ & - & 0 & 170 & 0 & 130.6 & 73.8 & 63.0 & 60.6 & 52.4 & 62.5 \\
\hline $\mathrm{C}$ & - & 0 & 170 & 40 & 133.2 & 78.1 & 85.4 & 80.3 & 77.1 & 80.2 \\
\hline D & TSP & 150 & 170 & 0 & 145.2 & 77.1 & 87.7 & 79.7 & 68.3 & 78.2 \\
\hline $\mathrm{E}$ & TSP & 150 & 170 & 40 & 139.8 & 84.3 & 97.9 & 87.9 & 75.0 & 86.3 \\
\hline $\mathrm{F}$ & Arad PR & 150 & 170 & 0 & 141.8 & 77.5 & 84.8 & 77.1 & 66.7 & 76.5 \\
\hline $\mathrm{G}$ & Arraias PR & 125 & 170 & 0 & 145.1 & 80.4 & 82.8 & 74.3 & 69.1 & 76.7 \\
\hline $\mathrm{H}$ & - & 0 & $100+70^{(4)}$ & 0 & 131.6 & 79.9 & 78.2 & 72.0 & 62.2 & 73.1 \\
\hline \multicolumn{5}{|c|}{ Coefficient of variation $(\%)$} & 7.7 & 6.3 & 12.5 & 8.5 & 13.8 & \\
\hline \multicolumn{5}{|c|}{ Analysis of variance, $p$-value for treatment effect } & 0.0223 & 0.0445 & 0.0002 & $<0.0001$ & 0.0053 & \\
\hline \multicolumn{5}{|c|}{ LSD (t-test, $\mathrm{p}<0.05)$} & 15.4 & 7.3 & 13.2 & 9.3 & 13.3 & \\
\hline
\end{tabular}

${ }^{(1)}$ The average total reducing sugars was $136.8,145.7,137.5$, and $142.4 \mathrm{~kg} \mathrm{Mg}^{-1}$ cane, respectively, in 2010, 2011, 2012, and 2013. ${ }^{(2)} \mathrm{TSP}$, triple superphosphate; and Arad PR and Arraias PR, Arad and Arrais phosphate rocks, respectively. ${ }^{(3)}$ Maintenance annual phosphorus rate as triple superphosphate. ${ }^{(4)} 100$ $\mathrm{kg} \mathrm{ha}^{-1} \mathrm{P}_{2} \mathrm{O}_{5}$ in the planting furrow and $70 \mathrm{~kg} \mathrm{ha}^{-1} \mathrm{P}_{2} \mathrm{O}_{5}$ side-dressed. 
Mehlich-1 and resin methods, respectively, classified as high according to Sousa et al. (2004).

The increase in sugarcane yield with corrective fertilization complementing phosphorus fertilization in the planting furrow, as observed in experiment 1 (Table 3), has been reported for soils with a low phosphorus availability in the state of Goiás and other regions in Brazil (Morelli et al., 1987, 1991; Rossetto et al., 2002; Gama, 2007; Sousa et al., 2015; Lisboa et al., 2016). This is explained, not only by the higher total rate of applied phosphorus, but also by phosphorus use efficiency in terms of higher cane yields when granular superphosphate or finely ground magnesium thermal phosphate (nearly $100 \%$ soluble in $2 \%$ citric acid, $1: 100 \mathrm{w} / \mathrm{v}$ ratio) are exclusively broadcast-incorporated instead of traditionally applied in the planting furrow, as shown in experiments with sandy soils (Reis \& Caballa-Rosand, 1986; Morelli et al., 1987, 1991; Rossetto et al., 2002) and a very clayey Oxisol (Rein \& Sousa, 2013). However, Santos et al. (2018b) did not find any significant difference in cane yield between broadcast-incorporation and furrow application of phosphorus.

Therefore, in most of the mentioned cases, phosphorus use efficiency by sugarcane in low phosphorus soils increases when fertilizers are applied to a much larger soil volume instead of at the bottom of the planting furrows (with $1.5 \mathrm{~m}$ row spacing). Given the low mobility of phosphorus in the soil (Sousa et al., 2016), broadcast-incorporation, compared with furrow application, allows a higher fraction of the root system to have access to the applied phosphorus, though much more diluted in the soil.

Corrective broadcast-incorporated phosphorus fertilization has been recommended in the Cerrado region for sugarcane (Rein et al., 2015; Korndörfer et al., 2017) and for crops in general (Sousa et al., 2004, 2016; Zancanaro et al., 2019). Fertilizer rates are recommended according to soil phosphorus availability and clay content as a surrogate of phosphorus adsorption capacity. This corrective fertilization is justified by the well-known and long residual effect of phosphorus application, which, in the case of annual crops, seems to be even more pronounced under no-tillage management (Sousa et al., 2016; Oliveira et al., 2019), a condition analogous to sugarcane ratooning. Under no-tillage, the long term recovery of broadcast-incorporated phosphorus in harvested products reached nearly $80 \%$ in a clayey Oxisol (Oliveira et al., 2020). Contrary to previous views that applied phosphorus is largely converted to forms unavailable to the plant, particularly in highly weathered soils, current analyses based on worldwide long-term experiments have pointed out that, once the soil phosphorus critical level is reached, phosphorus use efficiency by crops can exceed 80 $90 \%$, sustaining near maximum yields in the long run (Syers et al., 2008; Johnston et al., 2014).

In experiment 1 , the plant cane yield of treatment $\mathrm{H}$ for which the rate of $170 \mathrm{~kg} \mathrm{ha}^{-1} \mathrm{P}_{2} \mathrm{O}_{5}$ was split $\left(100 \mathrm{~kg} \mathrm{ha}^{-1}\right.$ in the planting furrow $+70 \mathrm{~kg} \mathrm{ha}^{-1}$ sidedressed before leveling soil surface) was comparable to that of treatment B with the same total rate applied

Table 4. Millable cane yields of plant cane and two ratoon crops in experiment 2 with sugarcane (Saccharum spp.) replant and a high phosphorus soil ${ }^{(1)}$.

\begin{tabular}{|c|c|c|c|c|c|c|c|}
\hline \multirow[t]{2}{*}{ Treatment } & \multicolumn{2}{|c|}{ Corrective fertilization } & \multirow[t]{2}{*}{ Planting furrow } & \multirow[t]{2}{*}{ Ratoon crop $^{(2)}$} & \multicolumn{3}{|c|}{ Cane yield } \\
\hline & Source & Rate & & & 2010 & 2011 & 2012 \\
\hline & & \multicolumn{3}{|c|}{ - } & \multicolumn{3}{|c|}{ - } \\
\hline A & - & 0 & 0 & 0 & 119.1 & 79.0 & 85.1 \\
\hline B & - & 0 & 170 & 0 & 118.8 & 77.5 & 84.4 \\
\hline $\mathrm{C}$ & - & 0 & $100+70^{(3)}$ & 0 & 124.2 & 79.0 & 83.2 \\
\hline $\mathrm{D}$ & - & 0 & 170 & 40 & 122.3 & 78.6 & 89.2 \\
\hline E & $\mathrm{TSP}^{(4)}$ & 150 & 170 & 0 & 130.4 & 77.7 & 89.8 \\
\hline \multicolumn{5}{|c|}{ Coefficient of variation (\%) } & 6.8 & 7.1 & 8.4 \\
\hline \multicolumn{5}{|c|}{ Analysis of variance, $p$-value for treatment effect } & 0.3352 & 0.9948 & 0.6337 \\
\hline \multicolumn{5}{|c|}{ LSD (t-test, $\mathrm{p}<0.05)$} & 12.9 & 10.5 & 11.2 \\
\hline
\end{tabular}

${ }^{(1)}$ The average total reducible sugars was $184.6,167.0$, and $137.5 \mathrm{~kg} \mathrm{Mg}^{-1}$ cane, respectively, in 2010, 2011, and 2012. (2)Maintenance annual phosphorus rate as triple superphosphate. ${ }^{(3)} 100 \mathrm{~kg} \mathrm{ha}^{-1} \mathrm{P}_{2} \mathrm{O}_{5}$ in the planting furrow and $70 \mathrm{~kg} \mathrm{ha}^{-1} \mathrm{P}_{2} \mathrm{O}_{5}$ side-dressed. ${ }^{(4)}$ Triple superphosphate. 
exclusively to the planting furrow, but was, on average, 10.6 $\mathrm{Mg} \mathrm{ha}^{-1}$ higher than that of treatment B for the ratoon crops (Table 3 ). This result is consistent with a higher phosphorus use efficiency when the fertilizer is applied to a larger volume of soil, allowing of a higher fraction of the root system to have access to this nutrient.

The commercial unground Arad phosphate rock and the finely ground $(96 \%<0.074 \mathrm{~mm})$ Arraias phosphate rock showed a similar performance to that of the superphosphate for corrective fertilization in treatments D, F, and G of experiment 1 (Table 3), which could make them attractive alternative sources for moderately acid soils if prices per unit $\mathrm{P}_{2} \mathrm{O}_{5}$ are lower than those for water-soluble fertilizers and if further experimental works confirm the present findings. Both phosphate rocks, with a solubility in $2 \%$ citric acid higher than $30 \%$, are classified as "reactive" by Brazilian regulations (Brasil, 2018). These and other reactive phosphate rocks have actually been evaluated for sugarcane, broadcast and incorporated in soils responsive to phosphorus fertilization, and shown to be equivalent or slightly inferior for plant cane, when compared with watersoluble sources (Rossetto et al., 2002; Tomaz, 2009; Caione et al., 2013; Rein \& Sousa, 2013; Sousa et al., 2015; Santos et al., 2018b).

The economic return of corrective phosphorus fertilization can be assessed considering the current costs (US\$1.00 $\approx \mathrm{R} \$ 4.10$ ) in 2019: $\mathrm{R} \$ 3.70 \mathrm{~kg}^{-1} \mathrm{P}_{2} \mathrm{O}_{5}$ for the soluble fertilizer (triple superphosphate or monoammonium phosphate); $\mathrm{R} \$ 35.00 \mathrm{ha}^{-1}$ for broadcasting the fertilizer (200-400 kg ha $\left.{ }^{-1}\right)$; $\mathrm{R} \$ 90.00 \mathrm{ha}^{-1}$ for incorporating the fertilizer with a disk harrow; $\mathrm{R} \$ 85.00 \mathrm{Mg}^{-1}$ for the price of millable stalks delivered to the sugar mill; and $\mathrm{R} \$ 30.00 \mathrm{Mg}^{-1}$ for harvesting, loading, and transporting stalks to the sugar mill. These figures allow to compute that the purchasing and application costs of $150 \mathrm{~kg} \mathrm{ha}^{-1}$ $\mathrm{P}_{2} \mathrm{O}_{5}\left(\mathrm{R} \$ 680.00 \mathrm{ha}^{-1}\right)$ are equivalent to $12.4 \mathrm{Mg}$ stalks [680/(85 - 30)]. In the case of experiment 1 , the yield increase with corrective fertilization was $13.4 \mathrm{Mg}$ $\mathrm{ha}^{-1}$ for plant cane and $17.7 \mathrm{Mg} \mathrm{ha}^{-1}$ for the average of the four ratoon crops (Table 3). Therefore, the investment would be paid off in less than two years after the purchase of the fertilizer, which makes corrective fertilization very profitable in the studied soil condition.
Significant yield increases in experiment 1 were also obtained with the annual maintenance phosphorus fertilization with triple superphosphate $\left(40 \mathrm{~kg} \mathrm{ha}^{-1}\right.$ $\mathrm{P}_{2} \mathrm{O}_{5}$ per year) side-dressed over the trash blanket (Table 3). The average yield increase of the four ratoon crops for treatment $\mathrm{C}$ with phosphorus fertilization in the planting furrow and annual maintenance was 17.7 $\mathrm{Mg} \mathrm{ha}^{-1}$ per year, in comparison with that of treatment B with phosphorus fertilization only in the planting furrow. The trend of higher yields in response to maintenance phosphorus fertilization was also observed for the treatments with corrective fertilization with triple superphosphate. The average yield increase for the ratoon crops under treatment $\mathrm{E}$ with corrective and annual maintenance fertilization was $8.1 \mathrm{Mg} \mathrm{ha}^{-1}$ per year in relation to treatment $\mathrm{D}$ without phosphorus maintenance fertilization. Over the five crops, the cumulative cane yield increase with the corrective fertilization of $150 \mathrm{~kg} \mathrm{ha}^{-1} \mathrm{P}_{2} \mathrm{O}_{5}$ as triple superphosphate was $77.6 \mathrm{Mg} \mathrm{ha}^{-1}$ for treatment $\mathrm{C}$ minus $\mathrm{B}$, whereas the cumulative yield increase with the annual maintenance fertilization of $160 \mathrm{~kg} \mathrm{ha}^{-1}$ $\mathrm{P}_{2} \mathrm{O}_{5}$ over the four ratoon crops was $73.7 \mathrm{Mg} \mathrm{ha}^{-1}$ for treatment $\mathrm{D}$ minus $\mathrm{B}$.

A compilation of experimental results (Rein et al., 2015) showed frequent cane yield increases around $10 \mathrm{Mg} \mathrm{ha}^{-1}$ per year with maintenance phosphorus fertilization of ratoon crops in low phosphorus soils in Brazil, but a lack of responses in other cases, most of them in soils with a higher phosphorus availability. It should be noted that the majority of these experiments was managed with pre-harvest burning and side-dress fertilizers incorporated into the soil. However, high yield increases were also reported for superphosphate applied over the trash blanket in low phosphorus Oxisols (Moberly \& Wood, 1970; Zambrosi, 2021). Given the low mobility of phosphorus in the soil, particularly in Oxisols (Nunes et al., 2011; Sousa et al., 2016), in experiment 1, the efficient use of surface applied phosphorus by sugarcane is likely due to a high density of superficial roots in the soil-trash interface (Vitti et al., 2008; Castro et al., 2021), which is easily observed in sugarcane fields. Improved moisture and temperature conditions on soil surface in the presence of trash (Dourado-Neto et al., 1999) may also play a role in the efficient use of phosphorus applied onto the trash blanket of sugarcane crops. 


\section{Conclusions}

1. The cane yields of the plant cane and ratoon sugarcane (Saccharum spp.) crops increase significantly with corrective phosphorus fertilization complementing the traditional application of phosphorus in the planting furrow, in a low phosphorus Oxisol.

2. The cane yields of the ratoon crops increase significantly with annual maintenance phosphorus fertilization in a low phosphorus Oxisol, being more pronounced in the absence of corrective phosphorus fertilization.

3. No significant yield increases with corrective or maintenance phosphorus fertilization are observed in the high phosphorus soil.

4. Both corrective and maintenance phosphorus fertilization practices, in addition to the traditional phosphorus application in the planting furrow, should be considered in sugarcane expansion or replanting areas for which soil phosphorus availability is below adequate.

\section{Acknowledgments}

To the Goiasa-Goiatuba Álcool Ltda sugar mill and to its staff, for providing the experimental areas, agricultural inputs, field labor, mechanization services, and technical support that made this work possible; and to Mr. José Carlos Pereira Barbosa, Mr. Jesuino de Souza Caldas, and Mr. Edson Douglas de Oliveira of Embrapa Cerrados, for their field work assistance.

\section{References}

BRASIL. Ministério da Agricultura, Pecuária e Abastecimento. Instrução Normativa no ${ }^{-}$39, de 8 de agosto de 2018. [Estabelece as regras sobre definições, exigências, especificações, garantias, registro de produto, autorizações, embalagem, rotulagem, documentos fiscais, propaganda e tolerâncias dos fertilizantes minerais destinados à agricultura]. Diário Oficial da União, 10 ago. 2018. 49p. Available at: <https://www.gov.br/agricultura/ pt-br/assuntos/insumos-agropecuarios/insumos-agricolas/ fertilizantes/legislacao/in-39-2018-fert-minerais-versaopublicada-dou-10-8-2018.pdf>. Accessed on: Apr. 82021.

CAIONE, G.; FERNANDES, F.M.; LANGE, A. Efeito residual de fontes de fósforo nos atributos químicos do solo, nutrição e produtividade de biomassa da cana-de-açúcar. Revista Brasileira de Ciências Agrárias, v.8, p.189-196, 2013. DOI: https://doi.org/10.5039/agraria.v8i2a2016.
CASTRO, S.A.Q. de; OTTO, R.; SANCHÉZ, C.E.B.; TENELLI, S.; SERMARINI, R.A.; TRIVELIN, P.C.O. Sugarcane straw preservation results in limited immobilization and improves crop N-fertilizer recovery. Biomass and Bioenergy, v.144, 105889, 2021. DOI: https://doi.org/10.1016/j.biombioe.2020.105889.

CLAESSEN, M.E.C. (Org.). Manual de métodos de análise de solo. 2.ed. rev. e atual. Rio de Janeiro: Embrapa-CNPS, 1997. 212p. (Embrapa-CNPS. Documentos, 1). Available at: $<$ https:// ainfo.cnptia.embrapa.br/digital/bitstream/item/169149/1/Manualde-metodos-de-analise-de-solo-2-ed-1997.pdf >. Accessed on: Nov. 22019.

CLIMATEMPO. Climatologia: Goiatuba-GO. Available at: $<$ http://www.climatempo.com.br/climatologia/1012/goiatuba-go >. Accessed on: Jan. 62020.

CONSECANA-SP. Conselho dos Produtores de CanadeAçúcar, Açúcar e Álcool do Estado de São Paulo. Manual de instruções. 5.ed. Piracicaba, 2006. 111p.

DOURADO-NETO, D.; TIMM, L.C.; OLIVEIRA, J.C.M. de; REICHARDT, K.; BACCHI, O.O.S.; TOMINAGA, T.T.; CÁSSARO, F.A.M. State-space approach for the analysis of soil water content and temperature in a sugarcane crop. Scientia Agricola, v.56, p.1215-1221, 1999. Supl. DOI: https://doi.org/10.1590/S0103-90161999000500025.

FRANCO, I.O.; SCOPEL, I.; ASSUNÇÃO, H.F. Unidades de mapeamento de solos sob cultivo de cana-de-açúcar em 2011: análise da expansão da cultura no Sudoeste de Goiás (Brasil). Revista do Departamento de Geografia, v.30, p.1-18, 2015. DOI: https://doi.org/10.11606/rdg.v30i0.89964.

GAMA, A.J.M. Sistema de rotação e adubação fosfatada na cultura da cana-de-açúcar no Cerrado. 2007. 86p. Dissertação (Mestrado) - Universidade Federal de Uberlândia, Uberlândia.

IBGE. Instituto Brasileiro de Geografia e Estatística. Produção Agrícola Municipal. Available at: <https://sidra.ibge.gov.br/ pesquisa/pam/tabelas $>$. Accessed on: May 182020.

JOHNSTON, A.E.; POULTON, P.R.; FIXEN, P.E.; CURTIN, D. Phosphorus: its efficient use in agriculture. Advances in Agronomy, v.123, p.177-228, 2014. DOI: https://doi.org/10.1016/B978-0-12-420225-2.00005-4.

KORNDÖRFER, G.H.; RAMOS, L.A.; REIN, T.A. Calagem, silicatagem, gessagem e fosfatagem para cana-de-açúcar. In: SILVA, F.C. da; ALVES, B.J.R.; FREITAS, P.L. de (Ed.). Sistema de produção mecanizada da cana-de-açúcar integrada à produção de energia e alimentos. Brasília: Embrapa, 2017. v.2, p.755-789.

LISBOA, L.A.M.; VIANA, R. da S.; PASCOALOTO, I.M.; HEINRICHS, R.; FIGUEIREDO, P.A.M. de. Efeitos da fosfatagem no desenvolvimento da cana-de-açúcar. Ciência e Tecnologia, v.8, p.31-41, 2016.

LUZ, P.H. de C; VITTI, G.C. Manejo e uso de fertilizantes para cana-de-açúcar. In: MARQUES, M.O.; MUTTON, M.A.; NOGUEIRA, T.A.R.; TASSO JÚNIOR, L.C.; NOGUEIRA, G.A.; BERNARDI, J.H. (Ed.). Tecnologias na agricultura canavieira. Jaboticabal: FCAV, 2008. p.140-167. 
MOBERLY, P.K.; WOOD, G.H. A comparison of methods of phosphate application to ratoon cane. In: ANNUAL CONGRESS OF THE SOUTH AFRICAN SUGAR TECHNOLOGISTS' ASSOCIATION, 44., 1970, Mount Edgecombe. Proceedings. Mount Edgecombe: South African Sugar Technologists' Association, 1970. p.155-161.

MORELLI, J.L.; DEMATTÊ, J.L.I.; SILVA, J.A.V.; BAPTISTELLA, J.R.; GIOVANETTI, L.Z. Efeitos da aplicação do superfosfato simples em área total e dentro do sulco. In: CONGRESSO NACIONAL DA SOCIEDADE DOS TÉCNICOS AÇUCAREIROS E ALCOOLEIROS DO BRASIL, 4.; CONVENÇÃO DA ACTALAC, 7., 1987, Olinda. Anais. Olinda: STAB, 1987. p.76-83.

MORELLI, J.L.; NELLI, E.J.; BAPTISTELA, J.R.; DEMATTÊ, J.L.I. Termofosfato na produtividade da cana-de-açúcar e nas propriedades químicas de um solo arenoso de baixa fertilidade. Revista Brasileira de Ciência do Solo, v.15, p.57-61, 1991.

NUNES, R. de S.; SOUSA, D.M.G. de; GOEDERT, W.J.; VIVALDI, L.J. Distribuição de fósforo no solo em razão do sistema de cultivo e manejo da adubação fosfatada. Revista Brasileira de Ciência do Solo, v.35, p.877-888, 2011. DOI: https://doi.org/10.1590/S0100-06832011000300022.

OLIVEIRA, L.E.Z. de; NUNES, R. de S.; SOUSA, D.M.G. de; BUSATO, J.G.; FIGUEIREDO, C.C. de. Response of maize to different soil residual phosphorus conditions. Agronomy Journal, v.111, p.3291-3300, 2019. DOI: https://doi.org/10.2134/agronj2018.11.0710.

OLIVEIRA, L.E.Z. de; SOUSA, D.M.G. de; FIGUEIREDO, C.C. de; NUNES, R. de S.; MALAQUIAS, J.V. Long-term phosphate fertilization strategies evaluation in a Brazilian Oxisol. Agronomy Journal, v.112, p.4303-4320, 2020. DOI: https://doi.org/10.1002/agj2.20324.

PENATTI, C.P. Adubação da cana-de-açúcar: 30 anos de experiência. Itu: Ottoni Editora, 2013. 347p.

RAIJ, B. van; ANDRADE, J.C. de; CANTARELLA, H.; QUAGGIO, J.A. (Ed.). Análise química para avaliação da fertilidade de solos tropicais. Campinas: IAC, 2001. 285p. Available at: <http://lab.iac.sp.gov.br/Publicacao/Raij_et_ al_2001_Metod_Anal_IAC.pdf>. Accessed on: Aug. 312019.

REIN, T.A.; SOUSA, D.M.G. de. Sugarcane response to phosphorus sources and placement in a very clayey Oxisol of the Brazilian Cerrado. In: CONGRESS OF THE INTERNATIONAL SOCIETY OF SUGARCANE TECHNOLOGISTS, 28., 2013, São Paulo. Proceedings. São Paulo: International Society of Sugarcane Technologists, 2013. p.477-485. Available at: $<$ https:// issct.org/wp-content/uploads/proceedings/2013/Agronomy.pdf $>$. Accessed on: Sept. 262019.

REIN, T.A.; SOUSA, D.M.G. de; SANTOS JÚNIOR, J. de D.G. dos; NUNES, R. de S.; KORNDÖRFER, G.H. Manejo da adubação fosfatada para cana-de-açúcar no Cerrado. Planaltina: Embrapa Cerrados, 2015. 12p. (Embrapa Cerrados. Circular técnica, 29).

REIS, E.L.; CABALA-ROSAND, P. Respostas da cana-de-açúcar ao nitrogênio, fósforo e potássio em solo de tabuleiro do sul da
Bahia. Revista Brasileira de Ciência do Solo, v.10, p.129-134, 1986.

RIBEIRO, N.V.; FERREIRA, L.G.; FERREIRA, N.C. Avaliação da expansão do cultivo da cana-de-açúcar no bioma Cerrado por meio de modelagem dinâmica da paisagem. Revista Brasileira de Cartografia, v.68, p.1-14, 2016.

ROSSETTO, R.; CANTARELlA, H.; DIAS, F.L.F.; VITTI, A.C.; TAVARES, S. Cana-de-açúcar. In: PROCHNOW, L.I.; CASARIN, V.; STIPP, S.R. (Ed.). Boas práticas para uso eficiente de fertilizantes. Piracicaba: IPNI, 2010. v.3, p.161-230.

ROSSETTO, R.; FARHAT, M.; FURLAN, R.; GIL, M.A.; SILVA, S.F. Eficiência agronômica do fosfato natural na cultura da canade-açúcar. In: CONGRESSO NACIONAL DA SOCIEDADE DOS TÉCNICOS AÇUCAREIROS E ALCOOLEIROS DO BRASIL, 8., 2002, Recife. Anais. Recife: STAB, 2002. p.276-282.

SANTOS, H.G. dos; JACOMINE, P.K.T.; ANJOS, L.H.C. dos; OLIVEIRA, V.Á. de; LUMBRERAS, J.F.; COELHO, M.R.; ALMEIDA, J.A. de; ARAÚJO FILHO, J.C. de; OLIVEIRA, J.B. de; CUNHA, T.J.F. Sistema brasileiro de classificação de solos. 5.ed. rev. e ampl. Brasília: Embrapa, 2018a. 356p.

SANTOS, V.R. dos; SOLTANGHEISI, A.; FRANCO, H.C.J.; KOLLN, O.; VITTI, A.C.; DIAS, C.T. dos S.; PAVINATO, P.S. Phosphate sources and their placement affecting soil phosphorus pools in sugarcane. Agronomy, v.8, p.1-15, 2018b. DOI: https://doi.org/10.3390/agronomy8120283.

SOIL SURVEY STAFF. Keys to Soil Taxonomy. $12^{\text {th }}$ ed. Washington: USDA, 2014. 360p. Available at: <https://www. nrcs.usda.gov/wps/portal/nrcs/detail/soils/survey/class/ taxonomy/?cid=nrcs142p2_053580 >. Accessed on: Apr. 52021.

SOUSA, D.M.G. de; LOBATO, E.; REIN, T.A. Adubação com fósforo. In: SOUSA, D.M.G. de; LOBATO, E. (Ed.). Cerrado: correção do solo e adubação. 2.ed. Brasília: Embrapa Informação Tecnológica, 2004. p.147-168.

SOUSA, D.M.G. de; NUNES, R. de S.; REIN, T.A.; SANTOS JUNIOR, J. de D.G. dos. Manejo do fósforo na região do Cerrado. In: FLORES, R.A.; CUNHA, P.P. da. Práticas de manejo do solo para adequada nutrição de plantas no Cerrado. Goiânia: UFG, 2016. p.291-357.

SOUSA, R.T.X. de; KORNDÖRFER, G.H.; SOARES, R.A.B.; FONTOURA, P.R. Phosphate fertilizers for sugarcane used at pre-planting (phosphorus fertilizer application). Journal of Plant Nutrition, v.38, p.1444-1455, 2015. DOI: https://doi.org/10.1080/01904167.2014.990567.

SPIRONELLO, A.; RAIJ, B. van; PENATTI, C.P.; CANTARELLA, H.; MORELLI, J.L.; ORLANDO FILHO, J.; LANDELL, M.G. de A.; ROSSETTO, R. Cana-de-açúcar. In: RAIJ, B. van; CANTARELLA, H.; QUAGGIO, J.A.; FURLANI, A.M.C. (Ed.). Recomendações de adubação e calagem para o Estado de São Paulo. 2.ed. Campinas: Instituto Agronômico, 1996. p.237-239. (IAC. Boletim técnico, 100).

SYERS, J.K.; JOHNSTON, A.E.; CURTIN, D. Efficiency of soil and fertilizer phosphorus use: reconciling changing concepts of soil phosphorus behavior with agronomic information. Rome: Food and Agriculture Organization of the United Nations, 2008. 108p. (FAO. Fertilizer and Plant Nutrition Bulletin, 18). 
TOMAZ, H.V. de Q. Fontes, doses e formas de aplicação de fósforo na cana-de-açúcar. 2009. 93p. Dissertação (Mestrado) Universidade de São Paulo, Escola Superior de Agricultura Luiz de Queiroz, Piracicaba.

VITTI, A.C.; TRIVELIN, P.C.O.; CANTARELLA, H.; FRANCO, H.C.J.; FARONI, C.E.; OTTO, R.; TRIVELIN, M.O.; TOVAJAR, J.G. Mineralização da palhada e crescimento de raízes de canade-açúcar relacionados com a adubação nitrogenada de plantio. Revista Brasileira de Ciência do Solo, v.32, p.2757-2762, 2008. Número especial. DOI: https://doi.org/10.1590/S010006832008000700020 .

VITTI, G.C.; OTTO, R.; FERREIRA, L.R. de P. Nutrição e adubação da cana-de-açúcar: manejo nutricional da cultura da cana-de-açúcar: In: BELARDO, G. de C.; CASSIA, M.T.; SILVA, R.P. da (Ed.). Processos agrícolas e mecanização da cana-deaçúcar. Jaboticabal: SBEA, 2015. p.177-205.

ZAMBROSI, F.C.B. Phosphorus fertilizer reapplication on sugarcane ratoon: opportunities and challenges for improvements in nutrient efficiency. Sugar Tech, v.23, p.704-708, 2021. DOI: https://doi.org/10.1007/s12355-020-00925-9.

ZANCANARO, L.; ONO, F.B.; KAPPES, C.; SEMLER, T.D.; VALENDORFF, J.D.P.; CORADINI, D.; VIDOTTI, M.V. Correção do solo e manejo da adubação. In: KAPPES, C. (Ed.). Boletim de Pesquisa 2019/2020. Rondonópolis: Fundação MT, 2019. p.111-136. 